\title{
E-learning i projektorienteret gruppearbejde
}

Gissur Jonsson

IT-Konsulent, BSCW-supporter

Driftsafdelingen, Institut VII/Center

Roskilde Universitetscenter

bscw-support@ruc.dk

http://www.ruc.dk/dat/driftsafdelingen/

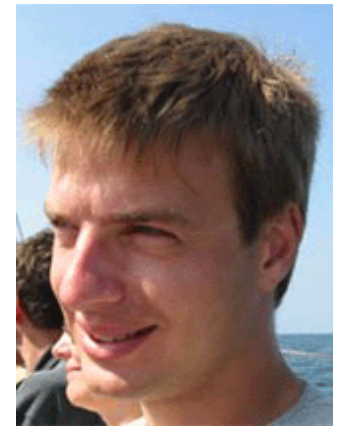

\section{Indledning}

Det første væsentlige tiltag, der forsøgte at give en E-learning platform til hele Roskilde Universitetscenter skete i marts 2003, da Budget- og Forretningsudvalget nedsatte en IT-taskforce til formålet. Denne taskforce anbefalede tre fokusområder, hvoraf en var rettet mod de studerende på RUC, og derfor relateret til det pædagogiske sigte i IT-anvendelsen. Fokusområdet udmøntede sig i et udvalg, der skulle anbefale en løsning til en studenterportal til studerende, der skulle samle alle nuværende oplysninger for de studerende, samtidig med at en række nye muligheder indenfor ITanvendelser skulle inkorporeres. Studenterportalen blev beskrevet i en endelig rapport, og resultatet blev fire ligestillede prioriteter: Administrative forhold, Studieforhold, Tjenester, Workspace. De to første kan under et beskrives som selvbetjening - begge handler om at give studerende direkte og nem adgang til oplysninger, der vedrører dem selv, og samtidig lette administrationen ved at give mulighed for at indlevere rettelser. Tjenester dækker over en lang række servicefunktioner, der bliver udbudt af RUC og andre organisationer. De spænder fra de store, oplagte tjenester, som E-mail, til den nyttige oversigt over togankomster og -afgange på RUCs nærmeste station Trekroner.

\section{Krav til E-learning systemet}

Den sidste prioritet er et samlet system til at tilbyde studerende (og ansatte) muligheden for følgende aktiviteter i elektronisk form (følgende er udpluk taget fra IT-taskforce-gruppernes afrapportering):

Den studerendes personlige arkiv:

Den studerende har adgang til at oprette og ajourføre et studiearkiv med fx noter, handouts/præsentationer, artikler, links mm. [...]

Showcase:

Den studerende kan tilrettelægge en del af arkivet som en "portefølje" om egne aktiviteter og kvalifikationer. [...]

Projektgruppeværktøj:

Systemet skal understøtte de studerendes projektgruppearbejde med features som arkiv, diskussionsforum, projektkalender og evt. diverse projektstyringsværktøjer og e-mail (som i forvejen er integreret i portalen). [...]

Vejlederkontakt:

Ved at give vejleder adgang til et projektgruppeområde (eller dele af det) kan dette udvides Kursusarkiv:

til at være et vejledningsværktøj.[...]

Kursusundervisning bør naturligt have et elektronisk arkiv med deltagerlister, kursusplan, litteraturlister, diverse undervisningsmaterialer i elektronisk form og et diskussionsforum (til fx uddybende diskussion, meddelelser, evaluering). [...] 


\section{Anvendelsen af BSCW}

På det grundlag blev der truffet en beslutning om at anvende BSCW (Basic Support for Cooperative Work, udviklet af Fraunhofer FIT og forhandlet af Orbiteam, Tyskland). Flere oplysninger kan findes på: BSCW.GMD.DE og www.orbiteam.de/en/index.html. Dette værktøj havde allerede været i brug i flere år på Instituttet for Kommunikation, Journalistik og Datalogi. Kort fortalt udbyder BSCW en lang række funktioner, der efterhånden er blevet fælles for de fleste samarbejdssystemer:

- Delte arbejdsområder med f.eks. dokumenter.

- Diskussionsfora.

- Kalender mm.

- Versionsstyring af dokumenter.

- Nem ajourføring med både direkte og indirekte notifikation om ændringer.

- Avanceret rettighedsstyring med nedarvende roller mm.

Hvad systemet ikke indeholdte af mere oplagte funktioner, kan nævnes en chat-funktion, en velfungerende messaging service og en striks opdeling mellem administrator og bruger. Den sidste anke ved systemet er faktisk en blanding af fordel og ulempe.

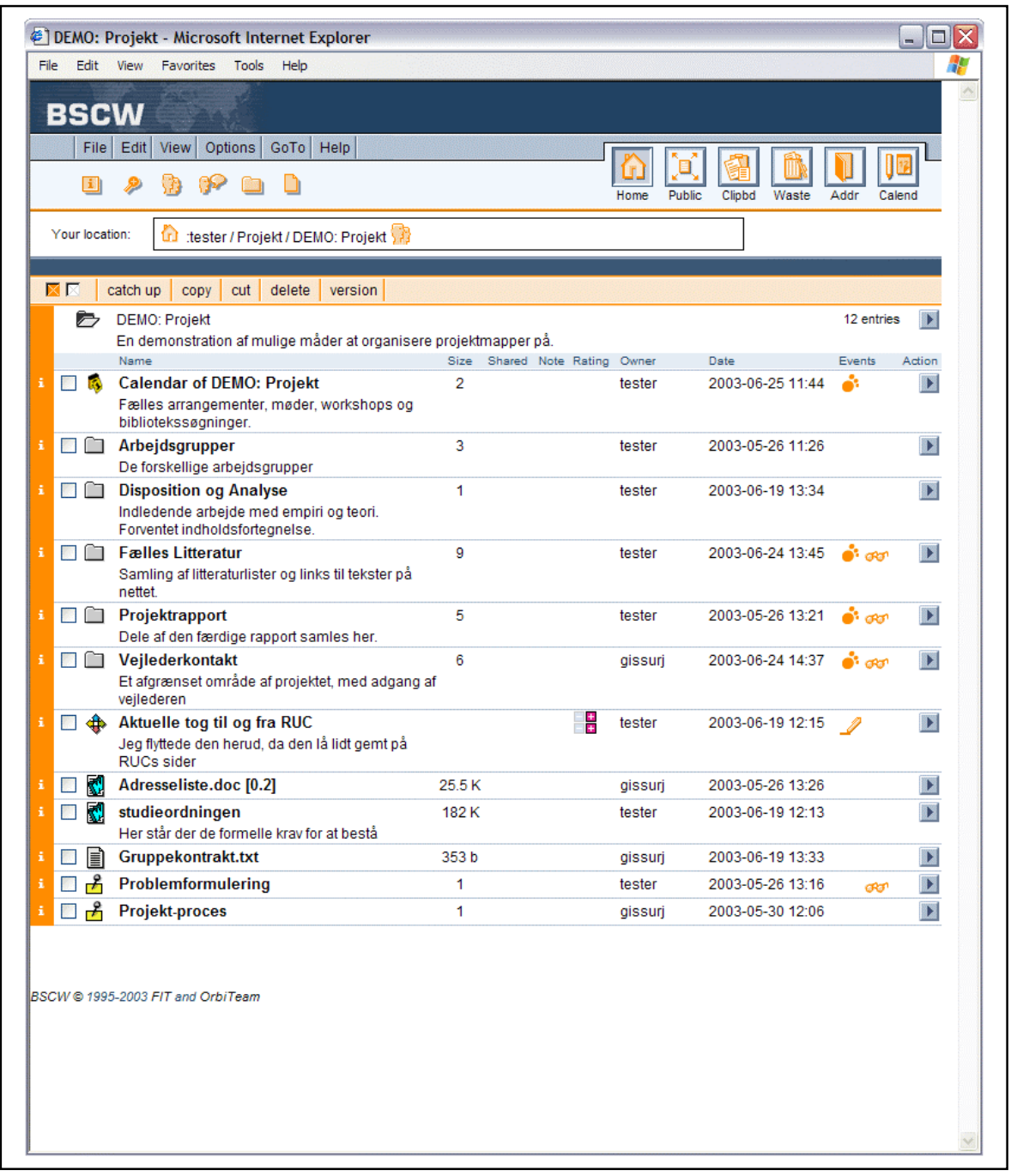

BSCW arrangerer alle sine objekter i mapper, der ligger rundt hos brugerne. En mappe er privat, sålænge der ikke er inviteret andre ind i den, hvorefter den bliver et delt arbejdsområde. Invitationen varetager brugerne selv, og oprydningen efter inaktive grupper klares ved en automatiseret proces, der holder øje med om BSCWs objekter er markeret til sletning (tømt fra skraldespanden hos ejeren), og ikke længere i brug hos nogen. Derved bliver objekterne meget sejlivede, idet de fleste deles mellem to eller flere, og oftest bare glemmes. 
Alle mapper, dokumenter og andre objekter i BSCW vises som en liste af indholdet i det arbejdsområde, man befinder sig i.

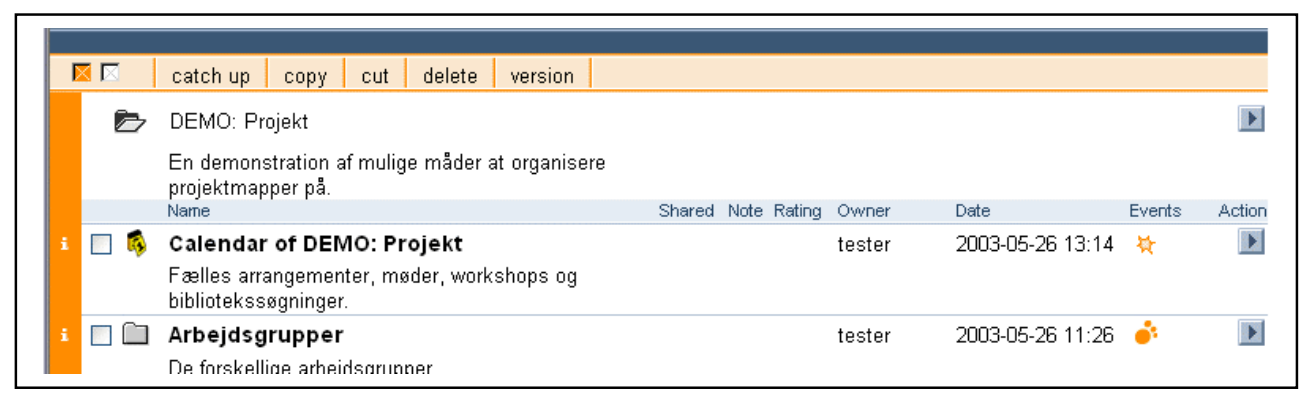

Kolonnerne i listen både informerer og bruges til at aktiverer. F.eks. aktiverer den yderste knap $\downarrow_{\mathrm{i}}$ kolonnen en kontekstafhængig menu, hvor man kan ændre dokumentet titel, erstatte det eller revidere den aktive version.

Der er en række menuer i toppen af skærmen, der giver adgang til de handlinger, der ikke hænger sammen med de enkelte objekter i BSCW (f.eks. brugerens indstillinger og oprettelse af nye objekter). Derudover er der en række genveje til at gøre de mest anvendte funktioner, og til at manipulere mange objekter samtidig.

Da brugerne i BSCW som udgangspunkt har ligeså vide muligheder for oprettelse, administration og nedlæggelse af egne og delte objekter som en traditionel administrator, giver systemet faktisk alle brugere magt til egen administration.

For at oprette en delt mappe med andre brugere kræver det kun tre korte trin:

Man starter med at navigere hen til den ønskede placering for den delte mappe. Dette kan omfatte et område, der allerede er delt med andre, hvormed der opbygges et helt hierarki af mappedeling.

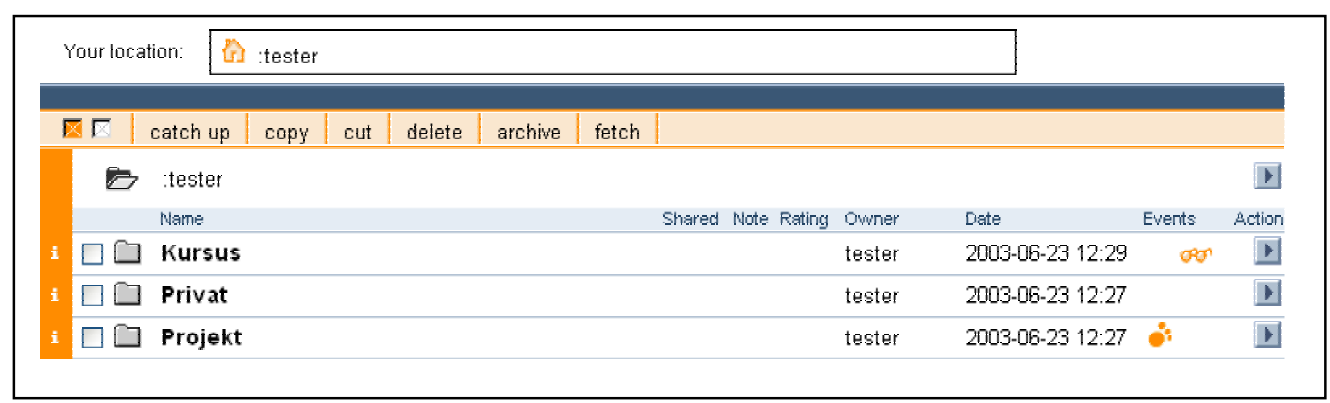




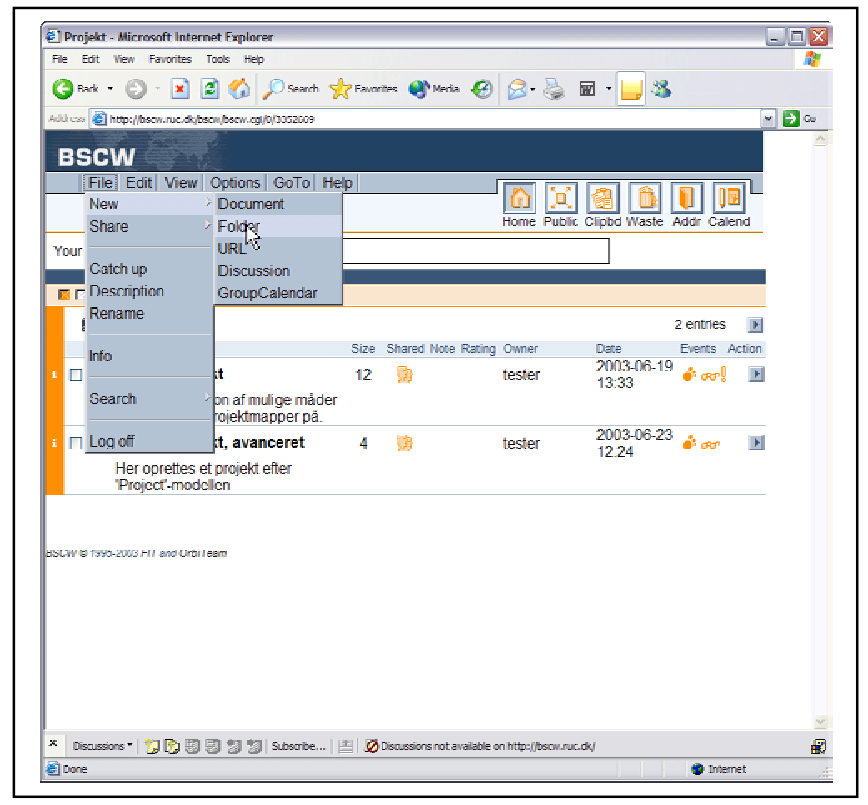

Der opretter man forst en mappe uden andre deltager end en selv og evt. de personer, der allerede havde adgang til placeringen. Nye objekter tilføjes ved at bruge en javascript menu, der skifter indhold efter den aktive mappe i BSCW. På den måde sikres det, at kalendre kun kan indeholde aftaler, diskussionerne kun kan indeholde indlæg og mapper kan indeholde de fleste typer objekter.

I det hele taget kan denne kontekst-afhægighed være med til at gøre indførslen i systemet vanskelig. Vi har forsøgt at afhjælpe dette ved at begrænse de mest avancerede handlinger til videregående brugerprofiler. Men stadig er den udstrakte brug af foranderlige menuer og flere genveje til samme handlinger en af problemerne for nye brugere. Det får dog sine fordele, når man har oparbejdet et tilstrækkeligt bekendtskab med systemet.

Dernæst indleder man invitationen af andre medlemmer. I dialogen til at tilføje medlemmer kan man vælge enten at markere i forvejen kendte personer, som man tidligere har arbejdet sammen med, eller at tilføje nye personer til en privat adressebog. Det sidste er mest almindeligt, og hvis man tilføjer deltagerne som email, afgører BSCW selv, hvorvidt der er tale om nye medlemmer (der sendes automatisk en invitation) eller allerede kendte brugere af systemet. Ved det viste skærmbillede er brugeren tester ved at invitere gissurj ind i mappen Test som restricted member - en særlig rolle, hvor kun læse-adgang er givet, og hvor rollen erstatter alle andre rettigheder, vedkommende måtte have i forvejen.

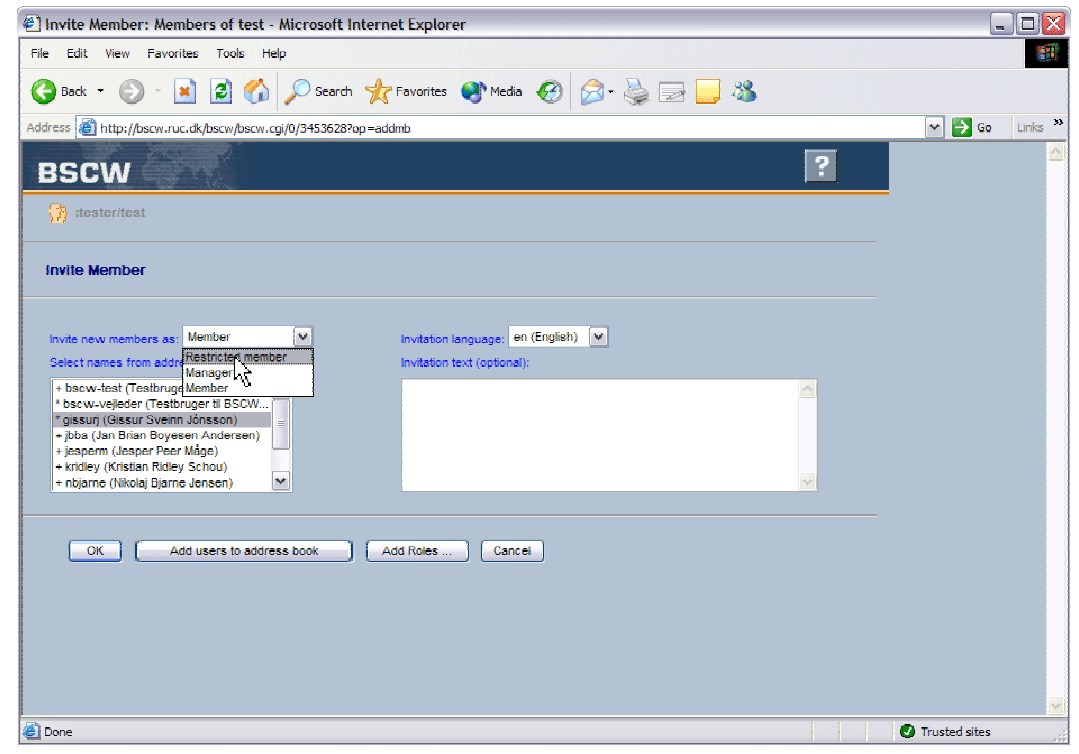


$\mathrm{Nu}$ har alle inviterede medlemmer adgang til mappen, samt alt hvad der lægges ind på de underliggende niveauer. Faktisk vil de nyinviterede se mappen på deres øverste niveau, uden adgang til mappe-ejerens private hierarki.Alle har derefter som udgangspunkt ret til at invitere flere medlemmer ind, flytte og slette indholdet og oprette nye mapper og dokumenter. Det er almindeligt, at en enkelt bruger opretter de indledende mapper, men dette svinger meget fra gruppe til gruppe, og det er sjældent i projektsammenhæng, at kun en bruger opretter hele arbejdsrummet (forstået som hele det delte hierarki af mapper).

Dette gør den centrale administration overflødig i det omfang, brugeren selv er klar over, hvad der skal til. Men det introducerer også et stort behov for formidling og træning af interesserede brugere i den mest egnede brug af BSCW. Da RUC altid har prioriteret den projektorienterede undervisning højest, giver BSCWs udprægede ligestillede, kollektive administration god mening. Som regel vil BSCW blive anvendt af projektgrupper, der dannes af de involverede selv, og hvis arbejdsrum udvikles og administreres af de mest interesserede i de enkelte grupper. Så længe at de langsomt udvider deres kompetence i systemet, vil administrationen ikke forekomme unødig besværlig eller uvedkommende. De har formodentlig ikke behov for at slette eller rydde op i gamle projekter, da indholdet stadig kan have interesse som arkiv (og alligevel deles med op til 8-9 andre personer), og da samarbejdet forekommer i små, tætknyttede grupper, forventes det heller ikke, at 'negativ' administration, som at fjerne andre medlemmer, slette dokumenter og anden destruktiv adfærd, vil blive et stort problem.

Et andet særkende ved BSCW er, at den hierarkiske model adskiller sig fra almindelige hierarkier ved at have flere veje igennem objekttræet fra de forskellige medlemmer ned til den samme mappe. Det betyder, at det ene gruppemedlem kan have projektgruppens mappe liggende i et indviklet hierarki med mange undergrene, mens det andet medlem bare har det liggende på det yderste niveau. Dette er en kolossal gevinst med hensyn til de studerendes mulighed for selvorganisering - særligt når man tænker på at niveauerne i hierarkiet også styrer forhold som notifikationer ved ændringer, deling og rettigheder. Desværre giver det også problemer, når det gælder at organisere på vegne af andre. I de hele taget gør de særlige karakteristika ved BSCW systemet særligt egnet til små, autonome klynger af rimeligt kompetente - og meget motiverede - gruppemedlemmer. Hvis systemet anvendes under disse problemer, begrænses support og administration til næsten ingenting. Men desværre giver de samme karakteristika store problemer ved opbygningen af større grupperinger, hvor en person (underviser) skal varetage et rum (kursus) for mange medlemmer med begrænsede rettigheder (kursister). I de tilfælde påføres underviseren unødigt besvær med administrationen, der skal foretages meget varsomt for at undgå enten for vide eller for snævre rettigheder til kursisterne. Omvendt oplever kursisterne ikke, at de kan nøjes med at anvende systemet efter egne behov, men skal tilegne sig en kompetence i et system for at bestå et kursus.

\section{Forskelle mellem gruppearbejde og en-til-mange undervisning}

I begge tilfælde forskydes de pædagogiske præmisser til at stå i skyggen af teknisk-administrative krav. Vores løsning indtil nu har været at kun anbefale systemet til det gruppearbejde, det er velegnet til. Kurser, temagrupper og læsegrupper kunne alle drage nytte af BSCW, men som situationen er nu, ønsker vi ikke at strække systemet til også at dække over aktiviteter, der er svære at administrere. Det betyder ikke, at undervisere bliver afvist hjælp til at oprette et kursus, tværtimod, men det betyder, at vi ikke kan give det første prioritet, og at vi helst ser, at et senere tiltag vil give underviserne det værktøj, der gør administrationen underordnet den pædagogiske hensigt. Det kan være, at vi kan udvide måden at administrere i BSCW til at gøre nuværende besværlige opgaver nemmere, eller det kan være at et helt nyt system kommer på tale til denne type aktivitet. Hele hensigten med systemet er at understøtte pædagogikken. I den nuværende form er denne hensigt klar, da de studerende igennem studiet i lige så høj grad oplæres i processen, såvel som fagligt. Projektarbejde på RUC er i høj grad også skærpelsen af de personlige og professionelle kvaliteter, der kræ- 
ves i samarbejdssituationer, og der kan BSCW være et nyttigt bidrag. Systemets understøttelse af koordinering lægger vægt på åbenhed og forhandling, som går i fin tråd med projektarbejdets præmisser som en hovedsagligt ikke-topstyret, ligestillet aktivitet imellem velmotiverede gruppedeltagere. Udover de ydre kriterier, såsom formelle deadlines, vejleders kritik og faglige krav, er det konsensus i gruppen, og den opbyggede synergi, der driver projektet videre.

Situationen er en anden i f.eks. kursussituationen. Her spiller åbenheden ind, da det samtidig kan opfattes som overvågning, at kursusholderen kan efterse elektronisk den aktivitet, der er lagt op til i kurset. I det hele taget skifter situationen til en mere top-styret og i særdeleshed ikke-ligestillet aktivitet, hvor værktøjet i høj grad nytter kursusholderen, mens kursusdeltagerne højest vil opleve en ny facet i undervisningsformen, der måske vil forsinke eller hæmme det pædagogiske formål med kurset. Derfor bliver det imperativt at opretholde åbenheden som en del af samarbejdsformen, så de studerende ikke føler sig nødsaget til at anvende systemet, men tilskyndes til det igennem det pædagogiske sigte. Det kræver kurser, der er diskussionsorienterede, deltagerdrevne og i høj grad både fleksible og unikke - i den forstand at indholdet også formes af deltagernes bidrag. De fleste undervisere vil bifalde en sådan udvikling, men da det samtidig også stiller store krav til forberedelse og pædagogisk professionalisme, må det givetvis også skabe behov for en efteruddannelse, der klæder underviserne på til denne udfordring. Denne udfordring er der endnu ikke lagt planer for på RUC.

\section{Tekniske årsager til valget af BSCW}

Da vi valgte BSCW, var adgang til kildekoden et vigtigt argument for systemet. Da BSCW er udviklet af et akademisk forskningsinstitut, og oprindeligt finansieret af offentlige midler, tilbydes BSCW også med en royalty free licens til uddannelsesinstitutioner, hvor man kun betaler for udvidelsespakkerne. I RUCs tilfælde har det betydet, at etableringsudgifterne til systemet har været minimale. Sammensætningen af en kommerciel virksomhed som primus motor i udviklingen af BSCW og muligheden for små ad hoc rettelser har gjort den nødvendige tilpasning og udvikling overkommelige, uden at der gives køb på sikkerhed og stabilitet i produktets fremtid. Derved sparer vi også personressurser, da vi bedre kan dedikere udviklings- og tilpasningsarbejdet til få og væsentlige områder, og bruge standardiserede løsninger på andre.

Den delvise åbne kildekode giver os rig mulighed for at integrere, diagnosticere og reparere små fejl og uhensigtsmæssigheder uden at involvere udviklerne i Tyskland. Vi har ændret ved den måde, der logges på systemet, så vi kan anvende vores egne databaser som grundlag, men stadig kun oprette brugere, der aktivt anvender systemet. Vi har tilpasset grænsefladen, så den omfatter det mest nødvendige for gruppearbejde - og ikke mere end det. De ekstra funktioner er stadig tilgængelige, men kræver at brugerne bevidst tager stilling til at udvide deres muligheder. Samtidig har vi også mulighed for at investere den tid, det vil kræve, at udvide BSCW til også at lette administrationen af kursusaktiviteter. Vi arbejder i øjeblikket på at udvide systemet til at kunne afgøre gruppemedlemskab ved dynamiske opslag $i$ en database, der vil blive dedikeret grupper og roller i forskellige sammenhænge på universitet. Derved kommer vi et skridt videre en tilpasning af BSCW til kursusarbejde. 